\title{
The Reform of Physical Education in Higher Vocational Colleges from the Perspective of Lifelong Physical Education
}

\author{
Fenglan Fan, Kejun Sun \\ Beijing Institute of Economic and Management, Beijing, 100102, China
}

\begin{abstract}
Key words: Lifelong physical education; Higher vocational colleges; Physical education; Teaching reform
\end{abstract}

\begin{abstract}
The idea of lifelong physical education is the soul of college physical education and the principle that must be adhered to in the teaching process of higher vocational colleges. The idea of lifelong physical education has rich connotation and wide range of relations; it is closely related to health education, quality education, skill education and happy education, which is very effective for the development of physical education in higher vocational colleges and has certain enlightenment to the reform of physical education. Based on the author's learning and work experience, this paper first interpreted the connotation of lifelong physical education, and then the paper discussed the effectiveness of lifelong physical education thought on the development of college physical education. Finally, this paper put forward the way of physical education reform in higher vocational colleges based on the concept of lifelong physical education.
\end{abstract}

\section{Introduction}

Physical education is a lifelong education process. Lifelong sports marked the development of social civilization, which is also the demand of pursuing health and longevity and improving the quality of life. School education is an important part of the whole education system. It is responsible for cultivating students' lifelong consciousness. In the latest law of "Sports and Health Curriculum Standards", the Ministry of Education issued that school physical education should lay the foundation for the formation of students' lifelong sports concept. Therefore, this paper summarized the present situation of physical education in higher vocational colleges and tried to take lifelong physical education as the guiding ideology of its reform with the purpose of exploring the effective countermeasures of physical education reform in higher vocational colleges so that to enable students to develop lifelong physical habits at the university and promote the lifelong physical education.

\section{Connotation of Lifelong Physical Education}

Physical education at colleges and universities should cultivate students' sports consciousness, form lifelong sports ideology, enhance students' interest in sports and improve students' physical ability. United Nations Educational Scientific and Cultural Organization (UNESCO) clearly stated in the International Charter of Sport: "physical education is a necessary factor of lifelong education in the whole education system, and there must be a global democratic lifelong education system to ensure that physical activity and sport practice can be applied to each person's life" , which further clearly put forward that physical education is not only a factor of lifelong education from the system level, but also a need depending on lifelong education system.

Paul Lengrand, a famous French educator, in his book "Introduction to lifelong education" he pointed out: "if the role of school physical education is regarded as unimportant and do not attach importance to school physical education; then, after the student entering the adult period, 
the sports activity does not exist. If you think of sports as the only thing in school, so sports activities in education has become an episode." Therefore, college physical education is not only a period of school education activities, but also a part of life to make the students in the school of physical education for life. Physical education is an integral part of education; therefore, physical education is a very important part of lifelong education, which plays an important role in lifelong education. In this sense, the study of lifelong physical education is not only the reform of the current higher vocational education sports system, the content and methods of the need, but also the need to cultivate qualified personnel, improve the quality of workers and improve the national physique.

The meaning of lifelong physical education includes two aspects: the first is to learn and take part in physical exercise from the beginning of life to the end of life with a clear purpose for the life so that it will make sports become an indispensable part of life; second, under the guidance of lifelong physical education with the systematization of sports and the goal of integration, it will provide people with the opportunity to participate in sports activities in different periods and different areas of life. Lifelong physical education is guided by the concept of lifelong sports and has school physical education model; lifelong physical education refers to receiving physical education, enhancing physical fitness and promoting health when encounter the unfair education at school so that students can still develop the physical habits and master of sports knowledge, technology, skills and adhere to physical exercise after graduation. Finally, the effectiveness of school sports can be extended for life to make people healthy and have physical and mental pleasure with life-long benefits.

\section{The Effectiveness of Lifelong Physical Education Thought on The Development of College Physical Education}

It is conducive to the increase of the value of college physical education. University is an important carrier to train senior specialized talents; the purpose of university education is to create all kinds of talents needed by society; the whole process of university education is the process of talent output and the value of talents can reflect the intrinsic value of the university to a certain extent. "According to a survey published on 1995 in the China Sports Daily with a survey of more than one thousand high school students from all walks of life, it showed that there are $90 \%$ of people having a weak sense of physical exercise and they neither have the ability to exercise nor the physical exercise habits. " This shows that the increase of social pressure, the acceleration of the pace of social life and the change of social life style lead to people's health condition is not optimistic; especially the intellectuals, they live 10 years shorter than the same population. It also shows that the nature of the intellectuals engaged in work has a great influence on their health, and a sharp decline in physical fitness and lack of physical exercise are not unrelated.

It is conducive to the formation of the theoretical system of school physical education in China. After the founding of the PRC, we began to build the schools with socialist characteristics. With the advent of reform and opening up, China has gradually formed a distinctive theoretical system of socialist education; however, from the current situation, there are still some drawbacks and some problems in guiding practice. The establishment of the idea of lifelong physical education is the requirement of the development of socialism with Chinese characteristics,

\section{Higher Vocational Colleges Sports Teaching Reform Based on Lifelong Sports Concept}

Strengthen the Importance of Propaganda in College Physical Education. Efforts on 
propaganda work is the basis for the implementation of lifelong physical education. With the development of modern science and technology, the informatization level of university has been increasing year by year. The form of physical education has gradually changed and changed the traditional teaching mode so that students can better accept physical education. Lifelong physical education as a concept is not easy to impart knowledge to students, which will only spend long time and by many ways to realize it. We implement a variety of means of publicity in physical education teaching, such as carrying out lectures on physical education, giving sports role-playing games, watching and listening to sports competitions, etc. In addition, we will vigorously promote the students to form a good habit of physical exercise.

Pay Attention to Imparting Knowledge in College Physical Education. With the diversification and individualization of physical education objectives, The process of physical education is also open; a variety of forms of teaching pour the vitality into the traditional physical education, which not only pays attention to the health of students cultivate the sentiment, but also promotes the physical and mental integration, especially in the field of pedagogy, psychology and other disciplines with the joint training of physical education teaching model and a new situation. However, the emergence of a variety of teaching concepts to a certain extent ignored the teaching of physical education. Further, the basic knowledge of the students is often not strong enough, which has a certain obstacle to the profound understanding of physical education. Therefore, to realize the lifelong physical education not only should use a variety of teaching methods and means, but also should be more firmly grasp the professional knowledge and lay a certain knowledge base.

Develop the habit of taking part in physical exercise actively in practice teaching. The value of lifelong physical education lies in guiding people to participate in physical exercise, and the habit of taking part in physical exercise also helps to get the idea of lifelong physical education. This requires the students to form a positive and active participation in physical exercise in college physical education and produce the awareness of lifelong participation in physical exercise in practice. Therefore, we should set up the consciousness of students' active participation in physical training in college physical education. Only through physical exercise and enhancing physical fitness, can students adapt to the needs of social development as soon as possible, increase the sense of happiness in life, focus on reality and actively participate in sports activities. At the same time, teachers should actively change the teaching concept, enrich the form of physical education and increase the fun of sports and cultural activities so that to let the students fully display their sports ability in physical exercise and promote students with a sense of accomplishment and joy. What's more, it also can develop good fitness habits at university so that to ultimately form lifelong sports thought.

Focus on building a harmonious relationship between teachers and students in physical education. In the process of physical education, teachers are educators, leaders and organizers. They want to pass some technical movements, sports knowledge and understanding to the students through a certain way. In this process, students are required to master certain technical movements and activities to promote their all-round development. Thus, the teacher is the leader of university teaching and students have a great relationship with teachers' knowledge, skills and concepts. In the traditional classroom teaching, the teacher is in the initiative position and the student can only obey and passively accept. Most of the students will have a certain emotional conflict, which is not conducive to receive good teaching results. In the new curriculum teaching, teachers and students are a new type of democratic relationship; teachers play the role of leader encouraging students to actively participate in sports activities to form a correct concept of sports. Harmonious relationship between teachers and students is an important foundation for the development of college physical education. Only teachers and 
students maintain a good emotional experience and meet their different needs, can they achieve good teaching results and truly deeply root the lifelong sports thought in people's hearts.

\section{Summary}

Lifelong physical education is the trend of sports development in the new century. It is very important for higher vocational students to develop the lifelong sports consciousness and the good habit of physical training. This is also the actual needs of the implementation of the National Fitness Program Outline. To cultivate the consciousness and habit of lifelong sports transfer students, we need to continue to carry out teaching reform, further improve the teaching model in order to achieve lifelong physical education goals through more scientific and reasonable teaching content, teaching method.

\section{References}

[1] Yin Zhenghui. Analysis on the Reform of Physical Education at Colleges and Universities under the Concept of Lifelong Sports[J]. Higher Agricultural Education, 2015, (04): 67-69. [2] Zhou Peng. Research on the reform of College Physical Education in China from the perspective of lifelong physical education[J]. Journal of Guangzhou Sports University, 2015, (01): 126-128.

[3] Wang Mian. Discussion on the Influence of College Physical Education Reform on Lifelong Physical Education[J]. Modern Sports Science and Technology, 2014, (32): 98+100.

[4] Shi Xiaoyang, Yue Xinpo. PE Teaching Reform in Middle School from the Perspective of Lifelong Physical Education[J]. Movement, 2014, (10): 10-11+17.

[5] Wu Juan, Lin Zhijun. Research on College Physical Education Reform from the perspective of lifelong sports[J]. Modern sports science and technology, 2013, (21): 105+107.

[6] Xu Li. Thinking and Exploration of Physical Education Reform in Normal Universities under the Concept of Lifelong Physical Education [J]. Journal of Hebei Normal University(Journal of Hebei Normal University), 2008, (03): 417-420.

[7] Wang Bing. On the Reform of Physical Education at Colleges and Universities from the Perspective of Lifelong Physical Education[J]. Journal of Changzhi University, 2008, (02): 74-77. 